\title{
M E D I A: DESIGNING A MODEL OF IFL LEARNING MATERIALS FOR FOREIGN WORKERS
}

\author{
Niknik Mediyawati ${ }^{1 *}$, Ninuk Lustyantie ${ }^{2}$, and Emzir ${ }^{3}$ \\ ${ }^{1}$ Universitas Multimedia Nusantara, ${ }^{2,3}$ Universitas Negeri Jakarta \\ *e-mail: niknik@umn.ac.id
}

\begin{abstract}
Communication gap because of linguistic difference and unavailability of specific learning materials become a problem of foreign workers working in Indonesia. A specific research that develops IFL learning materials to overcome these problems is needed. This study aims to develop and improve the quality of available IFL materials. Methodology used here is Research and Development, combining quantitative-qualitative approaches. The result of this study is: 1) M E D I A as a new framework learning materials with humanistic approach that presents multicultural domestic foreign workers' characters bound by a shared narrative on linguistic problems within business communication realm; and 2) M E D I A as mnemonic technique to embody those multicultural characters and values into teaching materials' books namely BIPA Business Communication. High-scoring of colleagues' evaluation and experts' validation confirms that the IFL is highly recommended to use. Having been implemented in large-scale class through Indonesian Proficiency Test (IPT), current study achieves effectively testing result which shows that this model of IFL learning materials is effective to use because it helps to improve the language skill of students.
\end{abstract}

\section{Keywords: MEDIA, mnemonic technique, learning materials' model development, IFL}

\section{E D I A: RANCANGAN MODEL BAHAN AJAR BAHASA INDONESIA UNTUK TENAGA KERJA ASING}

\begin{abstract}
Abstrak: Kesenjangan komunikasi karena perbedaan bahasa serta minimnya ketersediaan bahan ajar Bahasa Indonesia dialami oleh para tenaga kerja asing yang bekerja di Indonesia. Maka, dibutuhkan penelitian pengembangan bahan ajar BIPA yang bertujuan khusus untuk komunikasi bisnis. Dengan menggunakan metode research and development dan pendekatan kuantitatif-kualitatif, penelitian ini bertujuan mengembangkan dan memperbaiki model bahan ajar bahasa Indonesia. Penelitian ini menghasilkan: 1) MEDIA berupa rancangan baru bahan ajar humanis yang menghadirkan tokoh-tokoh tenaga kerja asing yang multikultur dengan ikatan cerita seputar permasalahan kebahasaan di dunia komunikasi bisnis; dan 2) rancangan berupa teknik mnemonic ini telah diwujudkan dalam buku ajar serial BIPA Komunikasi Bisnis. Berdasarkan penilaian teman sejawat dan validasi para pakar diperoleh rata-rata penilaian kelayakan yang menunjukkan bahwa model bahan ajar yang dikembangkan sangat layak digunakan. Setelah diimplementasikan pada kelas besar, diperoleh hasil uji efektivitas yang menunjukkan bahwa model bahan ajar ini efektif digunakan pada pembelajaran BIPA Bisnis karena dapat menaikkan kemampuan berbahasa Indonesia siswa.
\end{abstract}

Kata Kunci: MEDIA, teknik mnemonic, rancangan bahan ajar, BIPA 


\section{INTRODUCTION}

ASEAN Economic Community (AEC) brings some valuable attractions for foreign workers, with different linguistic backgrounds, to do their business in Indonesia. Seen from one perspective, for most Indonesian citizens, the existence of AEC is negatively perceived to bring some threats for the acknowledgement of Indonesian language as the national language to maintain. Seen from another perspective, this is a real opportunity for Indonesian language to be introduced to larger community, namely, international would-be workers. No one will deliberately want to feel alienated while living in other people's country. Naturally, they will adapt to their surroundings, including language and cultural surroundings. Indonesian government has supported the existence of Indonesian language to become not only national language but also international language, at least within AEC.

Government, through Ministry of Education and Culture's Language Development and Fostering Agency, has issued Minister's Decree No. 70 Year 2016 regarding Indonesian Language Proficiency Standards. Previously, Government has also issued Laws No. 24 Year 2009 regarding national flag, language, and symbol, as well as national anthem. Recently, two legal norms have been issued which address the procedure on how to employ foreign workers. First, Presidential Regulation No. 20/2018 on the Use of Foreign Workers in Indonesia (signed on March 26, 2018) Article 26, section 1, subsection c says that "Every Factory or Institution that employs foreign worker is obliged to facilitate education and training of Indonesian language towards foreign worker. Second, The Ministry of Manpower (MOM) issued regulation number 10 of 2018 regarding the Procedures for the Use of Foreign Workers (MOM Regulation 10/2018), signed on July 11, 2018; Article 4, section 4, subsection g. Legally speaking, the foundation has been laid to advance this issue; nevertheless, one big question remains unanswered: Is Indonesian business purpose learning materials intended for foreign workers available?

The Indonesian as Foreign Language (IFL) materials available now are typically for general purpose. As a consequence, the teachers should provide some necessary modifications of available materials in order to answer the specific needs of IFL students. IFL program and learning materials specially designed for specific purpose, such as business communication, is currently unavailable. By saying this, the selection process of IFL learning materials designed for specific purpose is a challenging task both for teachers and curriculum designers.

Current studies on IFL materials with specific purposes are still scarce. Amongst them are Suyitno (2018) who supports the view that Indonesian teaching and learning materials for foreigners have different emphasis and unique characteristics compared with Indonesian teaching and learning materials for general public (Suyitno, 2018). One of IFL salient features is highlight on different cultural backgrounds of its participants. Therefore, needs' analysis of the students as participants in IFL teaching and learning program as well as pedagogical norms of language instruction are certain prerequisites in the process of IFL materials' selection. Kusmiatun's three publications in this field address academic purpose. She observes that specific writings that elaborate learning topics which grab the attention of BIPA students are rarely found (Kusmiatun, 2016, 2017; Kusmiatun Suyitno, Widodo, \& Basuki, 2017). Yundayani, Emzir, \& Rafli (2017) discuss EFL materials on English writing topic in academic milieu while Kardijan, Emzir, \& Rafli (2017) address EFL for specific purposes in hospitality and tourism field. Defina (2017) addresses specific IFL material framed within agricultural context. In another context, 
Said identifies lexical and grammatical inappropriate collocations found in the writings of English-based IFL students while also describing the cause of these inappropriate collocations (Said, 2010). The main cause identified is because of negative transfer element from mother language of the students (English) into targeted language (Indonesian).

Unfortunately, all the above studies do not specifically address the issue of business communication purpose, meanwhile in reality, Indonesia has already been flooded with foreign workers. According to The Ministry of Manpower and Transmigration (MOMT), Republic of Indonesia, the numbers of TKA coming to Indonesia up to 2017 is around 85.974 workers. Their aims to work in Indonesia will be facilitated when they learn to communicate with their co-workers, with clients and consumers, as well as with their fellow members of society by using Indonesian language and for this to happen, they need to master the targeted language. This cause to master Indonesian language is strengthened institutionally when several foreign companies located in Indonesia, such as garment-based factory Hansae Utama Indonesia Co., and shoesbased factory Beesco Co., located in Karawang, oblige their foreign employees to use Indonesian language within workspace. The need to master Indonesian business communication amongst workers, with employers and Indonesian-user clients, is the practical context of current study. This business context is also heightened by the need to understand intercultural communication, given the pretext of cultural diversity in Indonesia. Here lies a specific need for IFL participants to recognize intercultural competence in order to avoid potential conflicts due to cultural differences (Murtiningsih, 2016).

On the topic of learning materials for business communication, the authors are indebted to the idea of incorporating everyday authentic dialogues into teaching activities as an important method of involving students (ESL students in New Zealand and Australia) in classroom activities and encouraging their contributions, recognizing their diverse cultural backgrounds in the classroom which pose challenges for teaching intercultural business communication (Zhu, 2007). In other aspect, Farhady \& Tavassoli (2018) indicate that most of the available tests (e.g., NBC, Praxis tests, TKT) are developed on the basis of experts' opinions following a top-down approach with a little or no attention to the voice or needs of the involved parties, especially teachers (Farhady \& Tavassoli, 2018). This current study will address this concern of integrating the needs of the involved parties, teachers and students alike, in developing more bottom-up IFL materials.

Current IFL business communication learning materials' model development study for foreign workers primarily refers to Indonesian Language Proficiency Test (UKBI) standards. Previous studies on similar topic rely quite dominantly on the framework of European (CEFR) and American-based (ACTFL) linguistic aptitude standards, such as in Japan context (Nakatani, 2012). Several studies on UKBI, such as Yanti (2015), Mus (2017), and Mukti, Andayani, \& Wardani (2017) problematize $U K B I$ as discourse on linguistic aptitude standards, not as the foundation to develop learning materials. Current study operates on practical level for the sake of foreign workers' enhanced capabilities to communicate in Indonesian business terms, thus it is founded on Intermediate level of IFL, as a minimum guidance. This study will do things differently, by elaborating specific idea of business communication IFL for foreign workers.

This current study offers three novelties: First, IFL for business communication purpose has never been elaborated nor performed practically in previous instances. Second, standard of 
fluency exhorted by this study is mainly referring to UKBI, not CEFR nor ACTFL, as commonly used in previous studies. Third, this study has also resulted in a novel methodological approach, namely MEDIA. It is a certain mnemonic technique or the so-called "donkey bridge" technique to develop language materials respecting the humanity aspect of Foreign Language Acquisition (FLA). MEDIA here confirms the embodiment of that spirit.

Here, the authors will argue that amidst scarcity of IFL learning materials for business communication as well as a growing interest of foreign people to study Indonesian language, this MEDIA model will be proper and sufficient to fill the gap. The main goal of this current study is to produce a model development of IFL learning materials for business communication purpose specifically designed to meet the needs of foreign workers.

\section{METHODS}

Method used in this study is mixed methods, combining qualitative and quantitative approach. Qualitative approach is used in subjective or uncontrolled nature of research such as when researcher gathers the data analysis of participants' needs taken from observation and interviews. Meanwhile, quantitative approach is used to analyze results from survey (questionnaire) starting from needs analysis towards implementation of learning materials developed by determining the numbers, percentage, and effectiveness testing conducted through t-testing in order to yield a specific difference when using both models of learning materials.

By employing Research and Development (R\&D) method, this design is based on learning materials' development theories as elaborated by Gall, Gall, \& Borg (2007), Hutchinson \& Waters (1987), Barnard \& Zemach (2003), and Tomlinson $(2003,2011)$. These five sets of theories show similarity in terms of paying attention to humanity aspect of learning materials' development and this MEDIA is in the same spirit with those thinkers. Other researchers have also shown interest to create their own unique mnemonic technique, in their own respective field of study, such as in Computer Science (Rawendy, Ying, Arifin, \& Rosalin, 2017).

During the process of using R \& D method, other types of methods will be employed such as survey, experiment, evaluation, and description. There are four steps to develop a model, namely (1) preliminary process, (2) design process, (3) validation, evaluation, and model revision which consists of (a) expert judgement, (b) small group try-out, (c) field try-out, and (4) model implementation (Gall, et al., 2007). Specifically for the second step, the design process, authors have developed authentic stages to design learning materials called M E D I A. The mnemonic technique of MEDIA will be shown in Figure 1.

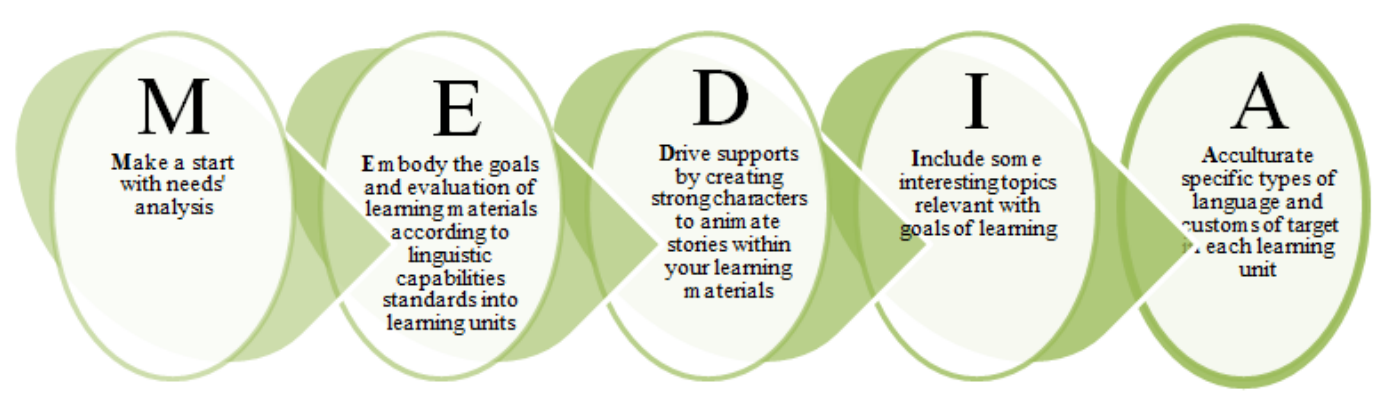

Figure 1. MEDIA: A Mnemonic Technique to Develop IFL Learning 
Research instruments used to analyze participants' needs' condition is 18dimensions questionnaire and series of interviews adopting those used by Ampa (Ampa, Basri \& Andriani, 2013). In the Questionnaire, authors pose several questions addressed to institution. Questions posed are concerning teaching materials conditions as well as syllaby expected to be inserted within learning materials, such as desired topics, methodology, outward appearance of the materials, lay-outs, colouring, and theoryladen evaluation as developed by Tomlinson (2003), Nation \& Macalister (2010), and Cunningsworth (1995). This type of evaluation will provide two different but complementary answers: 1) Unavailable, and 2) Available.

The details of the needs analysis process will be given as follows: The authors adopt the development approach by adapting to Borg \& Gall Model (1983). According to them, needs analysis is the first step of the method consisting of necessity analysis, weakness analysis, and need analysis. Need analysis, situation analysis and document analysis are concrete forms of preliminary research conducted in this stage. Needs' analysis is notably achieved through questionnaire dissemination, controlled observations and series of interviews in order to identify the needs of students and teachers of IFL Program in Universitas Multimedia Nusantara (UMN). To complete situation analysis, this research is focused on identifying learning materials and syllaby's condition available in IFL Program at UMN through questionnaire, observation and interviews with management and teachers of IFL Program at UMN.

\section{FINDINGS AND DISCUSSION Findings}

MEDIA is a proposed model to develop IFL learning materials on business communication for foreign workers. It is the result of this current study. The description and significance of each inscription above (M, E, D, I, and A) will be explained shortly below.

\section{M: Make a start with needs' analysis}

Tomlinson (2011) highlights the importance of engaging students in making decision for their own learning process. In order to know the needs of students, teachers and institutions, authors will propose needs analysis as the first step towards articulating what to answer. Authors will refer to criteria proposed by Tomlinson (2011) to start with needs' analysis. Nevertheless, questions addressed will be focused on task-oriented Indonesian materials as well as business communication purpose.

There are two main factors to analyze necessity. First, it should involve materials seen from the needs of participants. Second, it comes from the perspective of teachers or instructors. Based on the necessary factor from participants, there are 13 dimensions (listed as $\mathrm{A}$ to $\mathrm{M}$, in alphabetical), namely: rational participation needs, independence, self-development, creativity, teamwork, content, coherence, task-authenticity, cultural awareness, performance, accessibility, links, and stimulus.

Instruments used to analyze needs are interview sheets and questionnaire. In interview sheets, there are some questions posed to participants and instructors/institutions. The questions addressed specific conditions or circumstances on the expectation of learning materials and syllabus such as desired topics, methodology, materials outer appearance, lay out, coloring, and types of evaluation based on Tomlinson (2003), Nation \& Macalister (2010), and Cunningsworth (1995). Qualitatively, based on observations and interviews to teachers and program coordinator in IFL Program at UMN, data shows that Business Communication Syllabus and Learning Materials are unavailable, just a sheet of paper contains listed topics to use during the course of the program. Syllabus design 
is not based on students and teachers' needs' analysis, and it is not constructed based on certain theoretical frameworks making its assignments, goals, learning outcomes, evaluations and competencies to attain non-existent.

Based on situation analysis survey, data shows that criterium scoring for needs in all dimensions are 90. Highest score for each item (question) is one, total items are 90, and number of respondent is one (singular). Total score for data gathering is 24. Therefore, authors infer that the level of learning materials availability in IFL Program at UMN is unavailable since according to respondent, 24:90 means $26.67 \%$ from criterium total score (90). By continuum simple diagram, it is shown in Figure. 2.

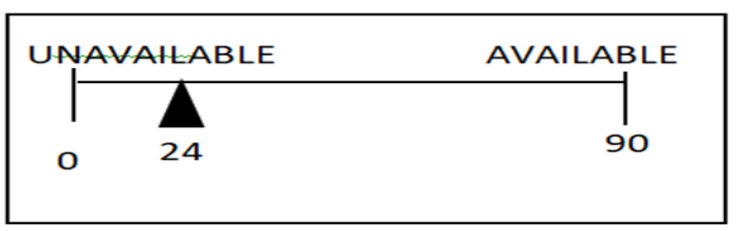

Figure 2. Level of Learning Materials' Availability in IFL Program at UMN

\section{E: Embody the goals and evaluation of learning materials according to linguistic capabilities standards into learning units

There are two Business

Communication books used by participants in IFL-UMN, namely, book I and book II. BIPA Komunikasi Bisnis I is a study book of Indonesian language with specific purpose, namely, business communication for IFL participants. This study book instructs and invites participants to show their linguistic awareness as communication speaker in interpersonal (social) as well as vocational behavior, both in its written and oral form, with specific emphasis on writing techniques and proper language mannerism as the banner of effective communication. Materials include sentences of expectation when graduating from school, supporting sentences when planning for the future, beautiful and attractive travelling notes, formal and non- formal types of communication in social media, colloquial language while communicating in social networking, communicating through telephone, how to properly reading job advertisements, important terms in interpersonal communication, writing a job letter, arranging a curriculum vitae and selfdescription, communicating while looking for a job, or when getting a job interview, and what to say in job interview itself. Overall, these materials are packed within structured task-based activities to do while running the program with specific target of achievement passing the Intermediate or Advanced UKBI level.

Based on the needs' analysis, by completing the BIPA Komunikasi Bisnis I program, participants will achieve these main competencies: 1) Participants are engaged to properly and correctly use Indonesian language while preparing to enter into workforce. 2) Participants are engaged to communicate well both in written and oral forms by applying correct and proper grammar in Indonesian language as a prerequisite factor before entering workforce. Along with these two main competencies, they have also set to master selected choice of additional competencies, namely 1) participants are able to write a job letter and arrange a curriculum vitae of his/her own by applying correct and proper techniques of writing and language as well as making the job letter or CV be attractive and interesting; 2) participants are able to make job interview recording by proving that their list of questions and the way to answer those questions are arranged with correct and proper writing techniques.

BIPA Komunikasi Bisnis II book has set two main competencies as the target: 1$)$ Participants are engaged to properly and correctly use Indonesian language while immersing in the workforce (at the office). 2) Participants are engaged to communicate well both in written and oral forms by applying correct and proper grammar in Indonesian language. Along with these two 
main competencies, they have also set to master selected choice of additional competencies, namely 1) participants are able to do presentation task by applying correct and proper techniques of speaking and grammar as well as making attractive and interesting slides; 2) participants are able to make job-related proposal as well as to write report of those activities with correct and proper writing techniques.

\section{D: Drive supports by creating strong characters to animate stories in learning materials}

Characters specially designed for these books are coming from multicultural background for the sake of accessibility of readers with his/her surroundings. One of the character's names in the book is Pertiwi. She is the main character. She plays the role as the host, Indonesia. This beautiful girl is having a family with Betawi (one of Indonesian ethnic) background, who befriends with Imija, a foreign worker from Korea. They seek jobs together, propose, interviewed and finally be accepted in the biggest media corporation in Indonesia. Their circle of friends are later expanded with friends from several countries, such as Jason, Lee, Ung, Syahrul, Michiko, and many others, representing different working ethic and distinct cultural awareness. Their unique stories fill the narration in each unit of learning within Komunikasi Bisnis I \& II.

By inserting these multicultural characters into the narration of Komunikasi Bisnis $I \& I I$, authors try to present twofold purposes. First, to present IFL business communication materials with local figures, and second, to represent interesting stories where people can identify with and feel belonging to. The characters animate variety of Indonesian and foreign people living and working in Indonesia's problems.

\section{I: Include some interesting topics relevant with goals of learning}

Topics covered in Business Communication $I$ book are making sentences of expectation when graduating from school, supporting sentences when planning for the future, beautiful and attractive travelling notes, formal and nonformal types of communication in social media, colloquial language while communicating in social networking, communicating through telephone, how to properly reading job advertisements, important terms in interpersonal communication, writing a job letter, arranging a curriculum vitae and selfdescription, communicating while looking for a job, or when getting a job interview, and what to say in job interview itself.

Meanwhile, topics covered in Business Communication II are presentation preparation, presentation, first day at the office: job contract, leaders (boss), staffs, and colleagues, getting around at the office, a positive working culture, leading a discussion, writing minutiae of a meeting, job meetings, writing proposal and activity report, getting promoted, welcoming speech and specific speech for various occasion.

\section{A: Acculturate specific types of language and customs of target in each learning unit}

IFL learning materials for foreign workers model development will be referring to IPT. This means that their linguistic competencies will be assessed as intermediate level, which then can be upgraded to the next three level: advanced, very advanced, and excellence.

Intermediate level covers specific linguistic competencies. Participant is considered capable enough to communicate in Indonesian, orally or in written form. In communication for the purpose of complex vocational, the intermediate-level participant still finds some difficulties and these difficulties are getting bigger when language is used in academic context. Advanced level covers better linguistic competencies. Participant is considered 
more than capable to communicate in Indonesian, orally or in written form. Nevertheless, the advanced-level participant still finds some difficulties when using Indonesian in complex academic and vocational demands. By elaborating on these hierarchical levels of linguistic competencies, IFL participants are actively involved within social, vocational, and academic types of communication.

In dealing with contextual types of communication, especially for the sake of foreign workers, it is important to note on the influence of culture and cultural awareness on mastering the target language. "EFL teachers and learners' perspectives on the text's potential for creating cultural awareness, cultural knowledge and attitude, intercultural skills, and cross-cultural understanding were significantly different. The EFL learners believed that the textbook covers the aforementioned factors well enough, whereas, the teachers believed that it falls short of sufficient attention to the factors." (Safa, Moradi, \& Hamzavi, 2015).

The importance of context in building communication, which is cultural milieu where specific communication occurs, has been confirmed thoroughly (Samovar, Porter, \& McDaniel, 2010). Different customs in specific culture will influence the practice of business communication by observing and asserting proper and improper behavior within specific context. Regulations related with non-formality, formality, assertiveness, interpersonal harmony, and social status can be found within each context of communication. In this very site occurs interpersonal communication within the context of international and domestic business.

Within the context of intercultural business communication, protocol will influence the way a relationship be established, greetings conveyed, personal appearance, gift bestowing, and taboo topics for discussion. Managerial style will also be different for each specific culture.
This difference lies in the process of negotiation, presentation, negotiator selection, business ethics, and participants' practice. In communication, sometimes we find the gap. To bridge that gap and fluently communicate in business, crosscultural communication understanding from many regions of the world is a necessary aspect. "The effective communication is highly influenced by proper understanding of cross-cultural communication" (Lewis, 2005, p. 94).

Based on this 'MEDIA' mnemonic technique to develop learning materials for IFL Business Communication purpose, current study has produced Business Communication Learning materials which include 2 Core Business Communication books, 2 Students' Assignment books, 2 Teachers' Assignment books, and 2 Reading Comprehension Learning Media books. This set of books are enriched with interesting themes, linguistic elements, and cultural varieties based on needs' analysis as well as imbued with the presence of multicultural characters which animate each unit of IFL for foreign workers that highlight the aspect of humanity in its broadest sense.

\section{Product Validation}

There are four experts agreed to validate current learning materials model development, a language pedagogist, learning materials' expert, IFL expert, and business communication/intercultural communication expert. There are five teachers/colleagues agreed to do similar validation process. Eighteen dimensions are used to validate worthiness of this study, i.e.: rational needs' of participants, independence, self-development, creativity, teamwork, content, coherence, taskauthenticity, cultural awareness, performance, accessibility, links, stimuli, guidance, choice, reflection/innovative, methodology, and flexibility. Total score for all criteria from four experts is 1440 . Highest score for each item is four, total dimension is 18 (from A to R), total items 
asked are 90 and total numbers of experts are four. Data gathering total score is 1301 . Therefore, it may be inferred that all experts agree on the worthiness of book series of BIPA Komunikasi Bisnis. When converted to percentage, it is $90.30 \%$, shown in Fig 3.

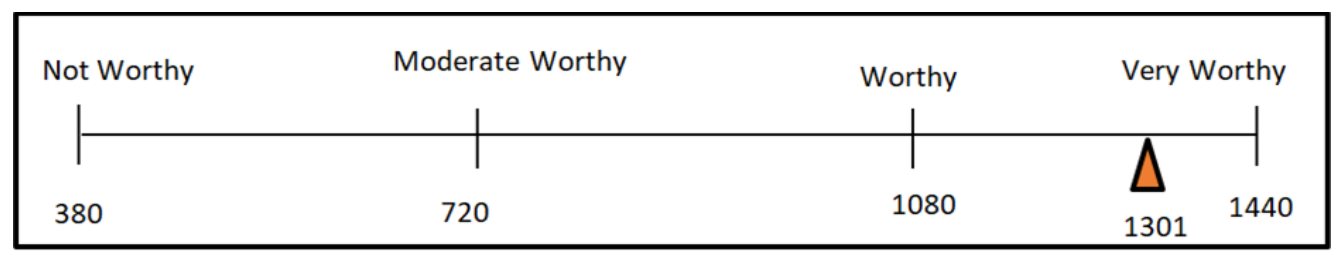

Figure 3. Level of IFL Learning Materials Model Development's Worthiness

\section{Product Effectivity}

Task-based Syllabus Design on IFL Learning Materials with Business Communication Purpose for Foreign Workers has been completed. BIPA Komunikasi Bisnis $I \& I I$ as the products of this study have been tested in big classrooms in IFL Program Satya Wacana University Salatiga and IFL Program at Bloombank Jakarta. To evaluate, there are four tools designed and prepared, i.e. four testing packets of UKBI (listening, grammar, reading, writing, and speaking). The table 1 below shows several testings conducted in order to prove gradual increase of students' test scoring before and after the implementation of MEDIA.

Based on Table 1, a gradual increase of scoring from first to fourth testing sessions occurs noticeably. Average gradual increase for all respondents is as follows: $\mathrm{T} 1$ to $\mathrm{T} 2$ average is $57 \%$, $\mathrm{T} 2$ to $\mathrm{T} 3$ is $57 \%$ and $\mathrm{T} 3$ to $\mathrm{T} 4$ is $75 \%$. Based on Gain T4-T1, total results overall is as follows: First respondent $72 \%$, Second respondent $72 \%$, Third respondent $72 \%$, Fourth respondent $76 \%$, and Fifth respondent $80 \%$. All respondents' average percentage in big classroom is $74.4 \%$.

Table 1. Big Classroom Effectivity Testing on Business Communication IFL Learning Materials Model

\begin{tabular}{llllllllll}
\hline No & Name & $\begin{array}{l}\text { Country } \\
\text { of Origin }\end{array}$ & Test 1 & Test 2 & Test 3 & Test 4 & GT2-T1 & GT3-T2 & GT4-GT3 \\
\hline 1 & Resp 1 & USA & 6 & 9 & 13 & 24 & 0.12 & 0.16 & 0.44 \\
2 & Resp 2 & Korea & 5 & 8 & 14 & 23 & 0.12 & 0.24 & 0.36 \\
3 & Resp 3 & Korea & 6 & 10 & 15 & 24 & 0.16 & 0.20 & 0.36 \\
4 & Resp 4 & Korea & 6 & 9 & 14 & 25 & 0.12 & 0.20 & 0.44 \\
5 & Resp 5 & Korea & 5 & 8 & 13 & 25 & 0.12 & 0.20 & 0.48 \\
\hline \multicolumn{2}{r}{ Average } & & $\mathbf{6}$ & $\mathbf{9}$ & $\mathbf{1 4}$ & $\mathbf{2 4}$ & & & \\
\hline Total & & $\mathbf{2 8}$ & $\mathbf{4 4}$ & $\mathbf{6 9}$ & $\mathbf{1 2 1}$ & & & \\
\hline
\end{tabular}

Figure 4 shows that the result is positively increasing for every student tested. Fig. 3 and Fig. 4 indicate that if average normalized gain $\langle\mathrm{g}\rangle \geq 0,70$, with high classification, it can be inferred that BIPA Business Communication book series is effective to use and worthy to defend because they are justifiably believed to increase language abilities of IFL participants. 


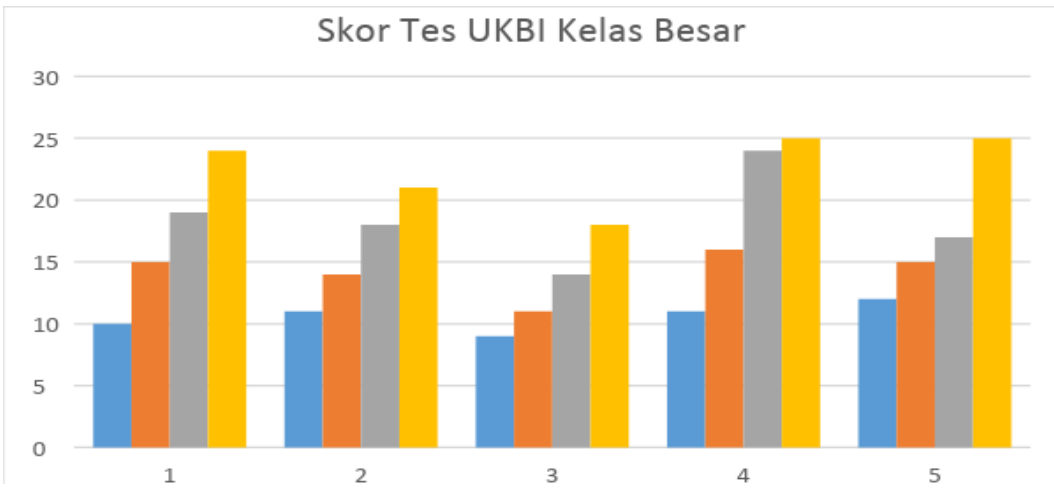

Figure 4. Big Classroom Testing on Business Communication IFL Learning Materials Model

\section{Discussion}

The ASEAN Economic Community challenges IFL teachers working in Indonesia to address the needs of potential and actual foreign workers with suitable learning materials that answer their specific needs to bridge the problem of communication gap between employers and employees. Most of foreign workers in Indonesia fail to comply to government law and ministerial decree, as well as the corporate regulation, which require them to speak Indonesian language at work. At this specific point, by designing M E D I A as an effective model of IFL materials for foreign workers, this study contributes to helping Indonesian government to facilitate foreign workers to comply with legal norms and regulations as well as to prevent factories, corporations, and institutions employing them to disobey the law.

Mnemonic-based materials development research has been addressed by Rawendy et.al. (2017), but this current study is taking it to another level by using local and multicultural characters as the illustration in the IFL materials. These characters intentionally used in the learning materials to help the students relate it with their own lifeworld. The main character is Pertiwi -- an Indonesian beautiful host from Betawi (ethnic origin in Jakarta) -- who made friend with Imija from Korea. Both of them were looking and applying for works and finally got accepted at the biggest media company in
Indonesia. At work, they were mingling with colleagues from other countries, such as Jason, Lee, Syahrul, \& Michiko. Aside of enhancing language skill in business communication, each lesson unit of the Business Communication books also teach students about cultural ethic of each country. The books also provide interesting stories of the characters which reflect the ordinary problems faced by foreigners living and working in Indonesia.

By inserting comic that 'can reveal the character through the pictures which can entertain the readers,' the participant students gradually find themselves along with their favorite characters, and they do not feel alienated because one or some of the characters are personification of their own self-understanding. By using mnemonic technique 'MEDIA', both teachers and students find their cognitive absorption be increased especially when they look at various visual characters within the books' narration. Due to its attractiveness, students tend to stay longer studying in the classroom rather than getting bored by typical textual materials and ordinary setting(s). This in turn will raise their "cultural awareness, cultural knowledge and attitude, intercultural skills, and cross-cultural understanding' to the level that students' mental disposition as adult learners is enabled to absorb the message without noticeable resistance. 
Other researchers have developed similar model based on other standard of proficiency, such as Common European Framework of Reference for Language (CEFR) (Kusmiatun, 2017; Defina, 2017; Nakatani, 2012) and American Council on the Teaching of Foreign Language (ACTFL) (Arumdyahsari, Widodo, \& Susanto, 2016). Current study on development of IFL learning material focusing on business communication for foreigners is based on $U K B I$, especially through the enactment of the Minister of Education and Culture Decree No. $70 / 2016$ on Indonesian language proficiency standard. The language mastery target to achieve for foreign workers wishing to work in Indonesia in social, education and research field is moderate (madya) level of proficiency. This moderate proficiency target is set to ensure that the workers not only survive but also be competent in their chosen field(s). By harmonizing BIPA Business Communication book series with these $U K B I$ proficiency standards, the result will increase collective self-confident of native IFL teachers and gradual process of language mastery for IFL students.

Several theories related to learning material development models (Gall, et al., 2007; Hutchinson \& Water, 1987; Barnard \& Zemach, 2003) are robust in needs analysis and language learning model designs, unfortunately their thoughts are lacking in humanistic spirit influenced with cultural attributes. Learning material selection theories (Tomlinson, 2003; Singapore Wala, 2003; Nunan, 2011) are elaborating what is lacking in their development material models. In accordance with Tomlinson's theory (2011), learning materials model development is an activity to supply information based on language activities inside the classroom in order to improve language learning activity. Enriched with cultural communication theories (Samovar, et al., 2010; Lewis, 2005), authors have shown that MEDIA as mnemonic technique, especially in stages $\mathrm{D}$ and $\mathrm{I}$, is what makes this study different compared with previous studies. Respecting and giving proper attention to humanistic aspects of language learning have already been achieved by other researchers in their previous studies, nevertheless, MEDIA has contributed deeper by animating the humanistic approach to developing materials for language teaching and learning, which in turn, be implemented in BIPA Business Communication book series.

The quantitative finding in product validation and effectivity is strengthened with interpretive data taken from in-depth interviews with teachers and students who participate in IFL activities related with the use of BIPA Komunikasi Bisnis I \& II book series. According to teachers, business communication teaching materials have complete syllabus and thorough task design, supplied with various and creative tasks as well as elaboration on many aspects of linguistic skills and thus empowering new teachers who want to autodidactically learn how to teach. Moreover, for more experienced teachers, BIPA Komunikasi Bisnis book series are completed with working books for students and teachers which are then considered helpful to boost their confidence to engage more responsibly in teaching and learning activities.

According to participant students, language and cultural elements found in BIPA Komunikasi Bisnis book topics, presenting through various multicultural figures, have been attractive to engage students to go deeper into IFL learning activity, and the availability of various tasks has been considered helpful to motivate students who want want to autodidactically learn in private. Attractive layout found in the book series, with beautiful images and pretty colors, has been singled out as boosting factor in fun learning activity. This all motivates students to learn their new targeted 
language in a more fun and passionate way.

\section{CONCLUSION}

While there were numerous efforts in developing Indonesian language learning model, they were not built based on the proficiency standard established by Indonesian government called UKBI. The previous models refer to the system established in Europe and US. This present study develops MEDIA as a model according to UKBI. Regardless government requires foreign workers to master speaking skill in Indonesian language -- as stipulated by the laws, presidential decree and ministerial regulation -- there were no learning materials available. This study provides the learning materials which can be used by institutions and individual workers to communicate in business context.

Furthermore, the previous models are lacking in relating the learning materials to the real life of the foreigners. Through multiple data analyses, this present study proves that the use of multicultural characters and themes related to the life of the foreigners, who are about to or already working in Indonesia, will significantly help them acquiring the language skill better.

Among the five elements of the model, from the need analysis (M) to the inclusion of culture and language elements (A), the key parts that make this model distinctive is on the "D" and "I" which focus on the use of the multicultural characters and themes related to the real life of foreign workers in Indonesia. This is in line with the result of the study's finding which show that IFL learners can gain perceptive understanding of both Indonesian culture and language thus enable them to interact with their peers and colleagues in Indonesian language as their second language.

This model can be used in two stages: first, madya (higher intermediate) level for foreigners who are looking for jobs (BIPA Komunikasi Bisnis I) and second, unggul (advance) level for IFL learners who have been working in Indonesian companies (BIPA Komunikasi Bisnis II).

As the implementation of this model is still limited at BIPA (IFL) courses provided by academic institutions, this model should be tested to wider participants by reaching out to foreign workers in companies and factories. While MEDIA is still limited to two levels only, other researchers with the same concern can develop models for other levels: terbatas (elementary), marjinal (higher elementary), semenjana (intermediate), sangat unggul (higher advance), and istimewa (highly proficient). Further research can also develop model in other fields aside of business communication, such as Indonesian language for diplomacy, house wives, tourism and hospitality.

\section{ACKNOWLEDGEMENT}

This research has been funded by several organizations and foundations. Researchers would like to thank Ministry of Research Technology and Higher Education, Universitas Multimedia Nusantara (UMN), Universitas Negeri Jakarta (UNJ), and invaluable sources for inputs that facilitate this study to be completely finished.

\section{REFERENCES}

Ampa, A. T., Basri D., M., \& Andriani, A. A. (2013). The development of contextual learning materials for the English speaking skills. International Journal of Education and Research, 1(9), 1-10.

Arumdyahsari, S., Widodo, H. S., \& Susanto, G. (2016). Pengembangan bahan ajar bahasa indonesia bagi penutur asing (BIPA) tingkat madya. Jurnal Pendidikan: Teori, 
Penelitian, dan Pengembangan, 1(5), 828-834.

Barnard, R. \& Zemach, D. (2003). Materials for specific purposes. In B. Tomlinson (Eds.), Developing materials for language teaching (pp. 306-323). London: Cromwell Press.

Borg, W.R. \& Gall, M.D. Gall. (1983). Educational Research: An Introduction (5th ed). New York, NY: Longman.

Cunningsworth, A. (1995). Choosing your coursebook. Oxford: Heinemann.

Defina. (2017). Materi imbuhan bahasa Indonesia dalam BPPB pada tingkat keterampilan berbahasa mahasiswa asing. Journal of Language and Literature Education (Jurnal Pendidikan Bahasa dan Sastra), 17(2), 175-187. doi: 10.17509/bs_jpbsp.v17i2.9656.

Farhady, H. \& Tavassoli, K. (2018). Developing a language assessment knowledge test for efl teachers: A data-driven approach. Iranian Journal of Language Teaching Research 6(3), 79-94.

Gall, M. D., Gall, J. P., \& Borg, W. R. (2007). Educational research: An introduction (8th ed). Boston, MA: Pearson Education.

Hutchinson, T. \& Waters, A. (1987). English for specific purposes: A learning-centred approach. London: Cambridge University Press.

Kardijan, D, Emzir, \& Rafli, Z. (2017). The gap between learning needs and its implementation in English for hospitality specific purposes program. English Review: Journal of English Education, 6(1), 125-135. doi: 10.25134/erjee.v6i1.779.
Kusmiatun, A., Suyitno, I., Widodo H. S, \& Basuki, I. A. (2017). Need assessment of learning materials of Indonesian for academic purposes for speakers of other languages. Researchers' world: Journal of Arts, Science \& Commerce, 8(3), 151-159. doi: 10.18843/rwjasc/v8i3/16.

Kusmiatun, A. (2017). Identifying features of Indonesian for speakers of other languages (BIPA) learning for academic purposes. International Journal of Social Science and Educational studies, 3(4), 1-17. doi: 10.23918/ijsses.v3i4p197.

Kusmiatun, A. (2016). Topik pilihan mahasiswa tiongkok dalam pembelajaran bipa program transfer kredit di UNY. Litera, 15(1), 138146. doi: 10.21831/ltr.v15i1.9773.

Lewis, R. D. (2005). Komunikasi bisnis lintas budaya. (D. Mulyana, Trans.). Bandung: Remaja Rosdakarya.

Ministry of Education and Culture's Language Development and Fostering Agency. (2016). BIPA dan UKBI. Retrieved from http://badanbahasa.kemdikbud.go.id/

Mukti, W. I., Andayani, \& Wardani, N. E. (2017). Pengajaran BIPA dan tes UKBI dalam upaya menjaga eksistensi bahasa Indonesia di era masyarakat ekonomi ASEAN. The 1st Education and Language International Conference Proceedings, 911-916. Retrieved from

http://jurnal.unissula.ac.id/index.php /ELIC/article/view/1317/1024.

Murtiningsih, B. S. E. (2016). The role of cultural competence to overcome intercultural communication conflict: Case study of Indonesian and Korean students in Kyungsung 
University, South Korea. Mediterranean Journal of Social Sciences, 7(6), 213-222. doi: 10.5901/mjss.2016.v7n6p213.

Mus, F. (2017, 1 Agustus). UKBI untuk seleksi masuk perguruan tinggi sebagai upaya meningkatkan kemahiran berbahasa Indonesia. Prosiding Ceramah Ilmiah dan Seminar Nasional Pengembangan Kemahiran Berbahasa Indonesia at Gedung Samudera, Rawamangun, Jakarta, Indonesia. Retrieved from https://www.researchgate.net/publica tion/321348589_ukbi_untuk_seleksi _masuk_perguruan_tinggi_sebagai_ upaya_meningkatkan_kemahiran_be rbahasa_indonesia.

Nakatani, Y. (2012). Exploring the implementation of the CEFR in Asian contexts: Focus on communication strategies. Procedia - Social and Behavioral Sciences, 46(2012), 771-775. doi: 10.1016/j.sbspro.2012.05.196.

Nation, I. S. P. \& Macalister, J. (2010). Language curriculum design. New York, NY: Routledge.

Nunan, D. (1988). Principles for designing language teaching materials. Guidelines: $A$ periodical for classroom language teachers, 10(2), 1-24.

Rawendy, D., Ying, Y., Arifin, Y., \& Rosalin, K. (2017). Design and development game chinese language learning with gamification and using mnemonic method. Procedia Computer Science, 116(2017), 6167. doi: 10.1016/j.procs.2017.10.009.

RoI, Presidential Regulation 2018 No. 20, The use of foreign workers.
RoI, Presidential Regulation 2018 No.10, Foreign workers.

RoI, Ministrial Regulation of Education and Culture 2016 No.70, Standard of Proficiency in Berbahasa Indonesia.

RoI, Ministrial Regulation of Manpower and transmigration 2018 No. 10, The use of foreign workers.

PNB Immigration Law Firm. (2018). Foreign workers regulation. Retrieved from http://www.pnbimmigrationlawfirm. com/foreign-workers-regulation-10$2018 /$.

Safa, M. A., Moradi, M., \& Hamzavi, R. (2015). Iranian EFL teachers and learners perspective on potentiality of top notch series for intercultural competence development. Iranian Journal of Language Teaching Research, 3(2), 47-66. Retrieved from https://eric.ed.gov/?id=EJ1127236.

Said, M. (2010). Ketidaklaziman kolokasi pembelajar BIPA dan implikasinya terhadap pembelajaran bahasa. Cakrawala Pendidikan, 29(2), 204213. doi: $10.21831 /$ cp.v2i2.340.

Samovar, L. A., Porter, R. E., \& McDaniel, E. R. (2010). Komunikasi lintas budaya. (I. M. Sidabalok, Trans.). Jakarta: Salemba Humanika.

Singapore Wala, D. A. (2003). A coursebook is what it is because of what it has to do: Editor's perspective. In B. Tomlinson (Ed.). Developing materials for language teaching (pp.58-71). London: Continuum. 
Suyitno, I. (2008). Norma pedagogis dan analisis kebutuhan belajar dalam pembelajaran bahasa Indonesia bagi penutur asing (BIPA). Jurnal Diksi, Jurnal Ilmiah Bahasa, Sastra, dan Pengajarannya, 15(1), 111-119. Retrieved from https://journal.uny.ac.id/index.php/di ksi/article/view/6561.

Tomlinson, B. (Ed.) (2003). Developing materials for language teaching. London: Continuum.

Tomlinson, B. (2011). Material development in language teaching (2nd Ed.). Cambridge: Cambridge University Press.

Yanti, N. (2015, 22 Oktober). Akselerasi dan optimalisasi penggunaan UKBI sebagai komponen peningkatan kemahiran berbahasa Indonesia.
Prosiding Seminar Nasional Bulan Bahasa UNIB 2015, 109-116. Retrieved from http://repository.unib.ac.id/11116/1/ 11-Nafri\%20Yanti.pdf.

Yundayani, A., Emzir, \& Rafli, Z. (2017). Need analysis: The writing skill instructional material context for academic purposes. English Review: Journal of English Education, 6(1), 59-69. doi: 10.25134/erjee.v6i1.771.

Zhu, Y. (2007). Using authentic crosscultural dialogues to encourage international students' participation in tutorial activities. Business Communication Quarterly, 70(1), 43-46. Retrieved from https://www.ufic.ufl.edu/pd/downloa ds/ici-

Activities/Telephone\%20Dialogue.p $d f$. 